\title{
Difficulties in the Development of Shaanxi Folk Culture Industry and Its Countermeasures*
}

\author{
Hongqiao Song \\ Xi'an Fanyi University \\ Xi'an, China 710105
}

\begin{abstract}
At present, Shaanxi faces the arduous task of deepening the reform in folk culture industry and urgently needs to establish new power in upgrade and development of folk culture industry, in order to create the premise for the new round development and smoothly realize the upgrade and innovative development of folk culture industry. In this process, Shaanxi meets predicaments like imbalanced incentive mechanism, low development efficiency of folkway resources and insufficient effective supply of folklore products and absence of innovation ability in folk industry. In order to get out of the predicament, we must further promote the supplyside structural reform of cultural industry and reunite new energy of industrial development; shape folk culture brands and lead the development pattern of folk culture industry; implement the innovative development strategy and optimize the structure of folk culture industry; deepen the reform of cultural administrative system and combine short-term and long-term benefits.
\end{abstract}

Keywords-Shaanxi folk culture industry; industrial upgrade; innovation-driven; supply-side structural reform

\section{INTRODUCTION}

Cultural industry is one of the pillar industries of economic growth at present. It proposes in the "13th Fiveyear" plan outline that we should achieve the goal of "basically complete the public service system of culture and let cultural industry become the pillar industry of national economy", and realize "put the social benefits in the first place, unify social and economic benefits and accelerate cultural reform and development". It indicates at new stage of economy, the development of cultural industry should emphasize quantity and value the connotative development on quality. [1] Therefore, according to the development characteristics of new stage of economy and the operation mechanism of folk culture industry, it is the inevitable course to realize the "innovative, coordinated, green, open and sharing" development of folk culture industry through concluding the dynamic mechanism in upgrade of folk culture industry, solving problems and exploring ideas in dynamic conversion. Shaanxi should establish and implement development idea of cultural industry, introduce and launch more excellent cultural products, build modern public service system of culture and create system in protection of excellent traditional culture; meanwhile,

*Fund program: Xi'an city social science fund planning project "Research on Innovative Development of Xi' an Cultural Industry under the Supply-side Structural Reform (16XF02). improve market system of folk culture, improve the level of cultural service and promote the development of folk culture industry.

\section{DEVElopment Status OF ShaANXI FOLK CUlture INDUSTRY}

The social and economic development promotes the growth of cultural needs. People's spiritual and cultural consumption is diversified. Folk culture products with folk customs and carriers like traditional manual skills, diet, costume, song and dance and dwellings attract more and more attention. The increase of folk culture products also drives the development of industry chain. New economic and social benefits make more folk culture embark on the road of industrialization development. Meanwhile, the development of folk culture industry makes more and more folk culture acknowledged by people and promotes the protection and development of folk culture.

With a long history, Shaanxi has abundant folk culture resources. The development of folk culture industry has unique position advantages. At the new stage of economic development, it faces new historic opportunities and has many deficiencies. From the perspective of citizens' cultural consumption level, according to the data issued by Xi'an investigation team of National Bureau of Statistics, the average consumption of urban residents of Shaanxi in culture, education and recreation is 2,207 yuan, lower than the national average level of 2209 yuan; the average consumption of rural residents of Shaanxi in culture, education and consumption is 464 yuan, far below the national average level of 486 yuan. According to the Score and Ranking of Cultural Consumption Index of China (2014) jointly issued by Renmin University of China and the Cultural Industry Division of Ministry of Culture, the cultural consumption level index of residents in Shaanxi province ranks seventh in our country. The ranking of comprehensive index of cultural consumption and cultural consumption ability in Shaanxi fails to enter the top ten. Obviously, it does not suit the cultural industry development in Shaanxi province. From the perspective of residents' cultural consumption in Shaanxi province, the cultural consumption of residents from the central Shaanxi plain, northern Shaanxi and southern Shaanxi has large differences. The growing rates of residents' cultural consumption expenditure in the central Shaanxi plain and the proportion 
of it in total consumption expenditures is the highest. The growing rate of residents' cultural consumption expenditure in northern Shaanxi is the lowest. It is moderate in southern Shaanxi. According to the development status of cultural industry in Shaanxi province, the development of folk culture industry of Shaanxi fails to correspond to the profound cultural deposits. Folk cultural products are not coordinated with people's increasing spiritual and cultural needs. Folk culture enterprises have small scale and lack influential big brands and products nationwide. The development degree of industrial cluster is low and hasn't formed stable industrial chain. According to the structure of cultural industry in Shaanxi, although the proportion of traditional cultural industry is high, the folk culture industry has insufficient investment and poor industrial competitiveness and lacks effective guarantee of capital source. Furthermore, the inharmonious industrial policy and operation mechanisms in regional management and the restricted support of folk culture industry also restrict the development of folk culture industry in Shaanxi. [2]

At present, the development of folk culture industry in Shaanxi faces new restrictions: (1) People lack consciousness of protection in folk culture. Modern popular culture and entertainment have great impact on traditional culture and art. Traditional folk custom fades. People lack the consciousness to protect folkway resources. The development of folk culture industry needs further improvement. (2) the living environment of folk culture is severe. The rapid economic and social development influences the survival and development of folk culture. Local languages, costume and custom activities as carriers of traditional culture in Shaanxi fades. Intangible cultural heritages like folk arts and skills inherited through oral and mental instruction are disappearing and endangered. (3) The system of folk culture inheritance needs improvement. With the penetration of overseas culture, young people no longer look forward to traditional festivals and gradually forget excellent traditional culture and customs. Besides, the unsound protective measures of folk culture also make folk arts lack worthy successors. Valuable material data spreading in the folks cannot be protected reasonably and will fail to be handed down from past generations. (4) Lack professional research teams. Folk arts like dance, painting and calligraphy are created by ordinary people and lack professional guidance. The artistic value and level are low so it is difficult for industrialization exploitation and the formation of scale merit. Yunnan has water culture and dress culture of the Yi nationality, Huizhou region has housing culture, Fujian has Tulou, Jingdezhen has porcelain and ceramics and Changsha has entertainment culture. In comparison, the folk culture industry in Shaanxi doesn't have leading projects and fails to drive the cultural industry. A complete and systematic operation mechanism must be established through referring to the successful practice of cultural industry in other regions of our country, in order to promote the development of cultural industry in Shaanxi province.

\section{DIFFICULTIES IN UPGRADE AND DEVELOPMENT OF FOLK CULTURE INDUSTRY IN SHAANXI AT THE PRESENT STAGE}

The current situation and characteristics of folk culture industry at the new stage of economy indicate Shaanxi province is in urgent need of adjusting the development of folk culture industry and the optimization and upgrade of industrial structure. In order to adapt to the development of quality-oriented economy under the New Normal, they should build endogenous power for the long-term steady development of folk culture industry, pursuing the long-term and sustainable development of folk culture industry and completing the industrial development model from quantitative growth to qualitative growth. Based on the protection, inheritance, development and innovation of traditional folk culture, they can develop ecological culture, historic culture, ideological culture, educational culture, religious culture, recluse culture and folk custom of Shaanxi, in order to make cultural resources into economic resources, promote folk culture production to wealth production and make the economic development of Shaanxi province realize industrial drive and all-round acceleration. According to the analysis on current situation and restraint factors of folk culture industry in Shaanxi at the present stage, the difficulties in upgrade and development include:

\section{A. Incentive Mechanism of Cultural Industry Is Unbalanced}

The essential issue in upgrade and development of cultural industry is the operation mechanism of cultural industry. The insufficient incentive mechanism is the difficulty in upgrade of cultural industry at the present stage: First is the restriction of cultural management mechanism. Although the reform of cultural administrative system in China defines the dominant position of cultural enterprises and institutions in the market and their independent legal person qualification, under the existing management system of cultural industry, the government only requires subordinate body to complete the task of cultural production and carry out regular management; supported by the public cultural resources of the country, cultural enterprises and institutions in system don't have obvious management innovation and pressure change. Although the cultural system makes for the normalized, systematic and regular development of cultural units, it is difficult to stimulate enterprises to consciously carry out "cultural innovation" and "cultural creation". Innovative platforms of folk culture should base on modern social organization, enterprise system and culture and art system, establish and improve the dynamic mechanism that stimulates cultural talents in natural culture transmission, spiritual creation, artistic talent and persistent pursuit. Second is the restriction of fund supply mechanism. On one hand, the direct financing of government and public purse restrict the unrestricted flow of resources required in cultural innovation, reduce the possibility of integrating cultural elements and restrict the recombination and collaboration of enterprises in different systems, industries and fields. On the other hand, the existing cultural system makes the social cultural resources gather in state- 
owned cultural enterprises, strengthens the monopoly of state-owned enterprises in the cultural field and restricts the entrance of private capital, failing to stimulate more social forces to participate in the cultural innovation.

\section{B. Development Efficiency of Folkway Resources Is Low}

The low degree of development and utilization of folkway resource restricts the development of folk culture industry at new stage and becomes the difficulty for upgrade of cultural industry: First, the supporting policies need improvement. On one hand, relevant policies fail to promote the development of folk culture. Sound coupling mechanism isn't formed to establish policies in land, revenue, government subsidies, social financing and diversified investment mechanism. [3] On the other hand, it lacks government funds and operational people. In the investment in infrastructure of folk culture, the private capital investment in construction of folk culture is still insufficient, especially lacking large project. Second, the human resource development is insufficient. The folk culture industry lacks professional management talents and corresponding talent training institutions and supply mechanism, restricting the sustainable development of folk culture industry. Besides, the absence of legislation of cultural industry, unsound management system and blocked operation mechanism influence the capital investment of folkway resource development and impede the dynamic conversion in upgrade and development of folk culture industry.

\section{Effective Supply of Folklore Products Is Insufficient}

The insufficient effective supply in the development of folk culture industry becomes the difficulty in dynamic conversion of folk industry at the new stage. First is the element supply. The output improvement of folklore products mainly depends on the development speed and scale of folk culture resources, neglecting the progressive increase of element efficiency. Second is the product supply. At the present stage in Shaanxi, low-end products are superfluous and high-end products are insufficient in folk culture industry. Meanwhile, the supply of public cultural products is insufficient and appears regional imbalance. The excess production capacity of structural culture highlights. Third is technology supply. Because of the absence of capacity of independent innovation, the long period of applying innovative technology to folk culture industry, the production efficiency of folk culture industry is low. Therefore, the insufficient supply impedes the upgrade and development of folk culture industry. [4]

\section{Innovation Ability of Folk Industry Is Absent}

The absence of innovation ability is the difficulty in upgrade and development of folk culture industry at the present stage. First, the capacity of independent innovation lacks. The insufficient capacity of independent innovation of cultural products cannot realize the quality upgrade and restrict the expansion of sales channel and marketing scope, making cultural enterprises fail to form effective competitiveness in the market. Second, the comprehensive innovation level is low. On one hand, the optimization of structure of cultural industry should be realized. The key is to implement innovation-driven development and improve the comprehensive innovation strength of cultural enterprises; on the other hand, the management system of cultural industry in China is inflexible and lacks innovation. The production, popularization and quality of cultural products lack international competitiveness. The quantity and quality of existing cultural products fail to meet the increasing cultural needs of residents. The practical experience of cultural industry development neither obviously promotes theoretical innovation nor organically combines with incentive mechanism of cultural industry, making the possibility frontier of folk culture production fail to expand and impeding the transformation from scale expansion to efficiency improvement.

\section{THOUGHTS AND COUNTERMEASURES IN REMODELING DEVELOPMENT IMPETUS OF FOLK CULTURE INDUSTRY IN SHAANXI}

After analyzing the difficulty in upgrade of folk culture industry at the present stage, we find thoughts in solving problems, seek the countermeasures and break the barrier of industrial upgrade, establish endogenous dynamic mechanism for the upgrade of folk culture industry under New Normal, in order to promote the further growth of local economy.

\section{A. Promote the Supply-Side Structural Reform of Folk Culture Industry and Reunite New Energy of Industrial Development}

In order to improve the supply quality of folklore products and promote the supply-side structural reform of folk culture industry, first, intensify the development of folklore products and its derivatives and carry out diversified development. It is necessary to reform the traditional folk culture, retain its elements with national features and endow it with creative and modern elements to improve the folkway resources. Besides, vigorously develop folkway derivatives. Folk culture products in Shaanxi are abundant and unique with strong regional features, such as clay sculpture, paper cut, New Year wood-block print, shadow puppet, diet, costume, drum music, local operas and Shehuo, temple fair and crispy noodles. People can base on tourism products and gifts, develop folk culture products that can meet consumers' cultural needs and enlarge consumer group and market of folkway resources and form new industrial chain. Second, develop and create base of folk culture industry and make major projects take the lead. The establishment of industrial parks and bases of folk culture makes for the rapid development of folk culture industry and integrates folk culture resources and attracts enterprises, projects, funds and talents. Seven historical and cultural theme parks have been planned in Shaanxi, including: Chinese ancestor cultural park depending on Yandi mausoleum and Huangdi mausoleum, Zhou cultural park depending on Chinese rites and music city project of Baoji, Qin culture theme park depending on Emperor Qinshihuang's Mausoleum Site Park and Qin Xianyang Palace Site, Han Culture theme park depending on Site of Chang'an of the Han Dynasty and Yangling Emperor 
Mausoleum of the Han Dynasty, Tang Cultural park depending on Qujiang cultural industry demonstration zone and Daming Palace National Park and Buddhist cultural park depending on Famen Temple. [5] Meanwhile, eight modern cultural industrial bases are constructed, including: entertainment base in Wenyi Road of Xi'an, Shaanxi animation creative base, red entertainment base in northern Shaanxi, Xi'an national digital publishing base, demonstration packaging base of Xi'an national printing industry, western film and television production base, logistics distribution center of northwest publications and trading base of Xi' an cultural relics and artworks. [5]

\section{B. Shape Folk Culture Brand and Lead Development Pattern of Folk Culture Industry}

The design, processing, production and consumption of folk culture products are the dynamic process in branding of folk culture resources. The creation of folk culture brands is the inevitable course to protect, inherit, develop and innovate in excellent folk culture resources and the key to implement the supply-side structural reform of folk culture industry. First, improve the market system of folk culture. Encourage capitals to enter the development areas of folk culture industry, carry out more extensive cross-border integration and integrate folk culture tourism, entertainment, media and animation with folkway resources. At the meantime, strengthen the transmission of folk culture brands, establish brand image of regional culture, and strengthen regional exchange and industrial alliance to form distinctive market system of folk culture industry in Shaanxi. Second, strengthen the intellectual property protection of folk culture brands. It is the fundamental way for healthy development of cultural industry to protect the intellectual property of folk culture brands and establish and improve industry standards. Third, train planner of folk culture brands. Cultural brands require plan and creativity. Folk culture is an important part of cultural industry. The design and development of folk culture brands require professional planner or designers. Fourth, protect folk custom item and successors of folk culture. In brand building of folk culture, folk custom items and successors of folk culture are material carrier of folk culture project. Folk culture and excellent folk resources can be better inherited through protection of them. The industrialization and branding of folk culture can promote the sustainable development of local economy.

\section{Implement Innovative Development Strategy and Optimize the Structure of Folk Culture Industry}

According to the development status of folk culture industry in Shaanxi, it is necessary to change idea, excavate innovative approaches to promote upgrade and development of folk culture industry and implement the innovation-driven development strategy: First, shape diversified, branding and professional commercial activity pattern. Governments and departments at all levels must realize the positive effects of folkway resources in local economic development and support it. Diversified development power of folk culture can form through the lantern show of Tang Paradise in folk festivals, Qujiang Cold Kiln pattern in folk custom history, Yuanjia Village pattern in Liquan in folk diet, Paper Cut Art in Huxian County in folk arts and crafts, art of shadow play in Hua County in Chinese folk art forms, Dangjia Village pattern in Hancheng City in folklore architecture and other religious faith, landscape of ancient towns, ancestral temple, gardening planting and folklore history passed on by word of mouth and accompanied by historical sites. Second, exploit various channels for consumption management of folklore products. "In order to gain better benefits, cultural industry must get returns on industrial chain." [6] Government authorities should break the routine and use innovative thinking to establish and improve the market operational mechanism of folk culture industry, set up consuming place of folk culture industry without the limitation of time and space, in order to let folklore products benefit from consumers. Third, strengthen the informatization construction of folk industry. At the new stage of economy, the innovation and development of folk culture industry must improve the use of modern technology and media and produce products with regional culture characteristics, suitable for the aesthetic judgment of the public and the exchange of multi-ethnic cultures. Furthermore, they should extensively use modern media like newspapers, magazines, radio, mobile phones and network to construct media platform of folk information, improving the communication between mass media and consumers, and providing convenience for the supply management and market consumption of folk culture industry.

\section{Deepen the Reform of Cultural Administrative System and Combine Short-Term and Long-Term Benefits}

Problems in upgrade and development of folk culture industry at new stage can be solved through improving the system supplies in development of folk culture industry and effectively combining short-term and long-term benefits. First, reform the cultural management system. On one hand, governments at all levels should establish better development policies and systems of cultural industry to improve the vitality and efficiency of cultural industry; on the other hand, governments must improve the way of macroscopic readjustment and control and use advanced technology like big data and Internet Plus and improve early-warning ability of macro economy. Second, balance the development between urban and rural folk culture industry. The market investment in Zhongnan folk culture industry centering on $\mathrm{Xi}$ 'an is large. The construction of corresponding cultural park and the cultural consumption market become mature. The consumption of people inside and outside the province gathers in these areas. In comparison, the development and utilization of folk culture resources in rural areas of Zhongnan region and the investment are inadequate. The chain of folk culture industry is weak. Except for folklore researchers and fans, foreign personnel seldom care for it. The government should coordinate the development of urban and rural folkway resources, guide cultural enterprises to innovate in the production mechanism, encourage enterprises to strengthen the innovation input of resource allocation, in order to form the production pattern that covers the cultural industry and realizes the efficiency of resource utilization. Third, implement "ecologization" strategy of folk industry development. Promote the inheritance and protection of 
excellent folk culture with the development of ecological economy as the core idea, accelerate the transformation and development of folk culture industry, build the structure of cultural industry with high technological content and low resource consumption as well as promote the quality and benefit of local cultural industry, in order to promote the joint development of society, resources and environment. In Zhongnan region of Shaanxi, it is necessary to inherit, protect and efficiently develop folk culture resources, improve the utilization efficiency of folklore resources, take the lead in ecological and intensive development of folk industry to promote the steady growth of cultural industry at new stage.

\section{REFERENCES}

[1] How Cultural Industry Become Pillar, http://news.xinhuanet.com/politics/2016-03/24/c_128829622.htm

[2] Liu Mengying. Research on Constraints in the Development of Folk Culture Industry of Fengxiang Clay Sculpture and Countermeasures [D], Xi'an University of Architecture and Technology, 2015: 22-31

[3] Zhuge Jinfei. Analysis on How Public Cultural Policy Guides the Sustainable Development of Folk Culture [J], Oriental Enterprise Culture, 2013(2): 52-57

[4] Li Hong, Zhang Jinyan. Supply-side Structural Reform and Transformation and Upgrade of Cultural Industry in Minority Areas [J], Journal of Dalian Nationalities University, 2016(4): 289-293

[5] Guo Yanna. Discussion on Upgrade of Shaanxi Folk Culture Industry [J], Journal of Xi'an Institute of Finance and Economics, 2012(3): 103-105

[6] Wu Shengyi, Xu Huihong. Discussion on the Industrial Development of Folk Culture-Selection on the Development Pattern of Rural Cultural Industry in Fujian Province [J], Issues in Agricultural Economy, 2007(1):60

[7] Zhang Wei. Analysis on Current Situation, Characteristics and Countermeasures of the Development in Shaanxi Cultural Industry [M], Shaanxi Cultural Development Report (2010) 